\title{
The Impact of Firm Size on Innovative Activity: An Analysis Based on Egyptian Firm Data
}

\author{
Prof. Hany Elshamy \\ Professor and Head of Economics Department, \\ Faculty of Commerce, \\ Tanta University, Egypt
}




\title{
The Impact of Firm Size on Innovative Activity: An Analysis Based on Egyptian Firm Data
}

\author{
Prof. Hany Elshamy
}

\author{
Professor and Head of Economics Department, \\ Faculty of Commerce, \\ Tanta University, Egypt
}

\begin{abstract}
The paper examines the relationship between the innovation activity and the firm size.This research administers a questionnaire- based survey developed from the UK Innovation Survey (CIS). The survey covers quantitative and qualitative information addressing the innovation activities in the small and medium sized firms in Egypt during the period 20102012. The sample covers manufacturing firms in different regions in Egypt such as north, middle and Upper Egypt as well. The paper uses a logit model to study the relationship between the innovation activity and firm size and an orderedlogit model to study the relationship between the sources of innovation and performance. This paper demonstrates there is a positive relationship between size firm and innovation. The main policy implications of these results are that innovation policies should explicitly identifytheir major objective and target group of firms.
\end{abstract}

Keywords: Innovation Activity, Egyptian SMEs, Firm Size

JEL Classification: O31, O32 


\section{Introduction}

Mansfield (1968) argues that innovation is the key stage in the process leading to the full evaluation and utilisation of an invention or the creation of a new type of industrial organization. In fact, Schumpeter identified five forms of innovation (Deakins and Freel, 2003): the introduction of a new good, the introduction of a new method of production, the opening of a new market, the conquest of a new source of supply of raw materials, as well as new forms of organisation.

In a series of important papers, Von Hippel $(1974,1976)$ has described the concept of “ sticky knowledge" and how problem solving efforts in innovation are concentrated upon inter-firm relations where knowledge is "sticky" ( i.e. costly to transfer between firms). In this type of innovative process, the locus of problem solving lies within a process of interaction with customers who become a primary source of information. Symmetrically, it might be expected that process innovations on the other hand will frequently depend upon product innovation and differentiation in the supplying industry. The role of equipment investment may be particularly important in this regard, with both knowledge generation and human capital formation an outcome of equipment investment activity.

Why should small firms differ from larger firms differ from large firms both in the decision to commit resources to innovation and in the process itself? There are many possible differences between small firms and large firms in their role as innovators, Storey (1994) argues that the ability of smaller firm to provide something marginally different, in terms of service or good, which distinguishes it from other goods or services provided by larger firms. If this is the case, differentiation and specialization in product characteristic space may be the source of a relative advantage for small firms, i.e. in product as opposed to process innovation (see for example Hoffman et al, 1998). Management texts frequently draw 
attention to organisational differences, especially in the relative merits of flexibility against routine. The following table (drawn from Deakins and Freel 2003) is suggestive of the advantages and disadvantages of small firms in innovation activities.

Table 1 Advantages and disadvantages of small firms in innovation

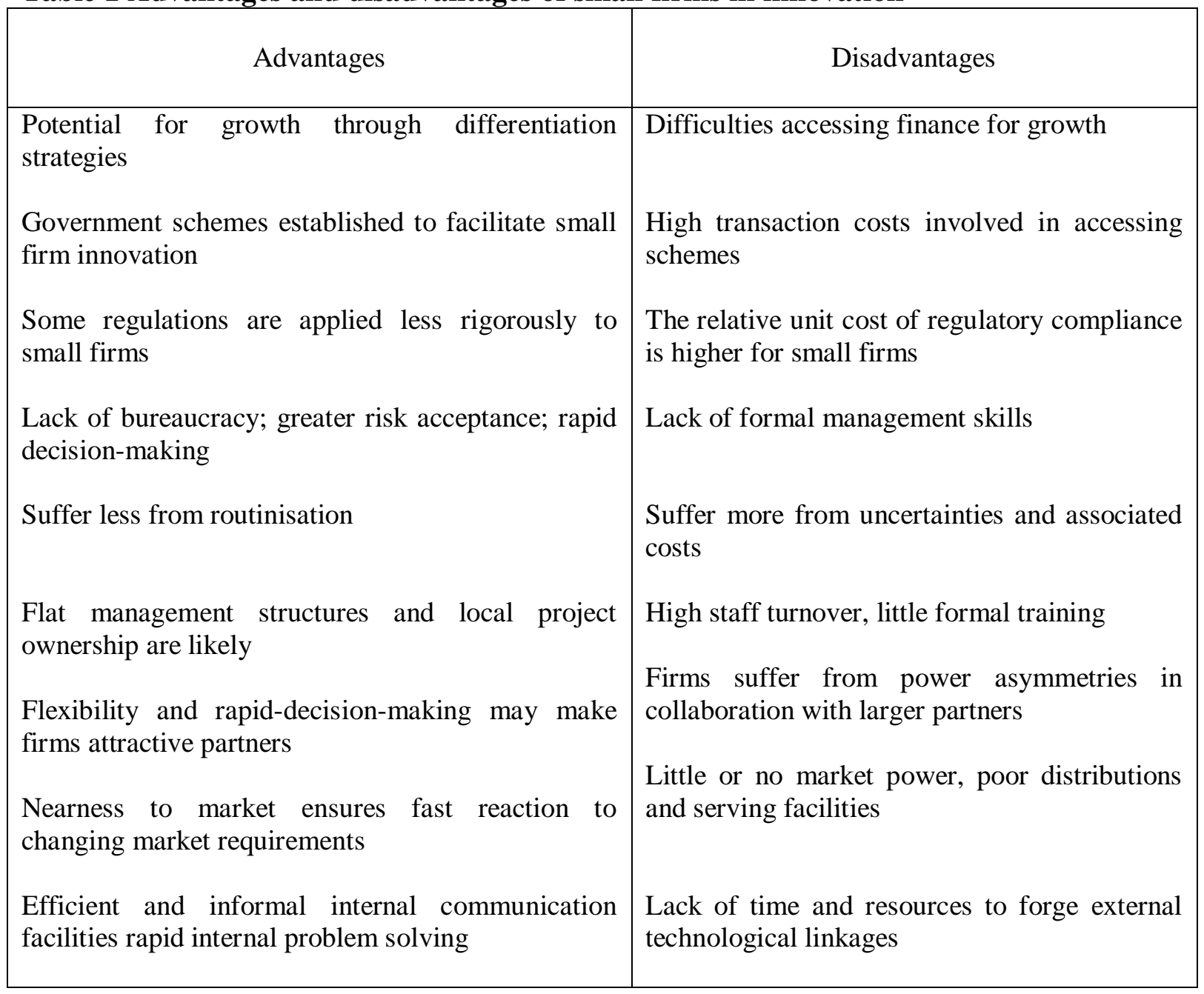

Source: Deakins and Freel 2003

Of course, in economics, Schumpeter's (1942) hypothesis regarding the relationship between size, market power and innovation has been extensively investigated since Schumpeter(1942), the idea that size may confer some advantage on firms deploying resources in order to innovate has provided a staple for over forty years in the empirical literature. Schumpeter's original ideas embraced both the impact of size per se as well as the impact of market structure, i.e. that market power- ex ante- was more conductive to 
innovation than competition. At least the promise of ex-post market power is of course generally regarded as a condition for innovation.

The advantages relating to firm size are generally recognised as consisting of some or all of the following (see e.g. Simeonidis, 2001: Cohen, 1995):

- The fixed costs and economies of scale associated with the innovation process requiring large sales volume,

- Potential for economies of scope,

- Access to external finance,

- Risk diversification,

- Insofar as large size is associated with market power, large firms may be better able to appropriate returns from innovation.

Note that the first four of these amount to capital market imperfections. There are however some counter-arguments. Simeonidis in particular notes the possibility of control loss in large bureaucratic organisations, echoing the management literature cited above. Empirical evidence on the role of size per se on innovation is rather mixed, and has been dogged by both econometric and by measurement issues. The focus on R\&D expenditures or employment- at best an input into the innovation processmay of course bias the results in favour of large firms that have formal $R \& D$ departments and against smaller firms who may have individuals who are performing similar roles but are not so classified. Patents on the other hand vary considerably in their use-both though time and according to the so called "appropriability conditions"- across industries. Precisely because of the continuing debate about the measurement of inputs and outputs relating to innovation, surveys such as the Community Innovation Survey (CIS) may be extremely valuable in extending our knowledge.

This paper aims to study the relationship between firm size and innovation in Egyptian Small and Medium Sized Firms.

This paper is organised as follows. The next section discusses the literature review. Section 3 presents data collection. Section 4introducesthemethodology. Section 5 concludes. 


\section{Literature Review}

In his theory of Economic Development (1912) and in Capitalism, Socialism and Democracy (1942) Schumpeter proposed two major alternative patterns in innovative activities (Malerba\&Orsenigo, 1995). The first one, labelled as Schumpeter Mark I or "creative destruction" (see, Breschiet al, 2000), is proposed in the earlier theory of Economic Development, 1912. In this work, Schumpeter examined the typical European industrial structure of the late nineteenth century characterised by many small firms. According to this view, the pattern of innovative activity is characterised by technological ease of entry in an industry and by a major role played by new firms in innovative activities. Breschiet al (2000) argues that firms introduce this kind of innovation did not innovate before: it is called "widening".

The second one, labelled Schumpeter Mark II or "creative accumulation" (see, Malerba\&Orsenigo, 1995; Breschiet al, 2000), is proposed in Capitalism, Socialism and Democracy, 1942. In this later work Schumpeter discussed the relevance of the industrial R\&D for technological innovation and the key role of large firms. According to this view, the pattern of innovative activity is characterised by the prevalence of large firms who innovate on a more routine basis. Breschiet al (2000) call this "deepening".Schumpeter Mark II hypothesis regarding the relationship between size and innovation has been investigated many times in the years since his death. The following table identifies some of the more influential studies: 
Table 2: The relationship between innovation and firm size (empirical studies)

\begin{tabular}{|c|c|c|c|c|c|c|}
\hline Study & sample & Country & Data & $\begin{array}{l}\text { Dependent } \\
\text { Variable }\end{array}$ & Firm size & Result \\
\hline $\begin{array}{l}\text { Scherer } \\
(1965)\end{array}$ & $\begin{array}{l}448 \text { large } \\
\text { industrial } \\
\text { firms }\end{array}$ & US & $\begin{array}{l}\text { Cross } \\
\text { section }\end{array}$ & $\begin{array}{l}\text { Patents } \\
\text { issued in } \\
1959\end{array}$ & $\begin{array}{l}3 \text { measures of } \\
\text { firm size for } \\
1955\end{array}$ & $\begin{array}{l}\text { Patents increase with } \\
\text { firm sales but at less } \\
\text { than proportionate rate }\end{array}$ \\
\hline $\begin{array}{l}\text { Scherer } \\
(1984)\end{array}$ & $\begin{array}{l}196 \\
\text { industries }\end{array}$ & US & $\begin{array}{l}\text { Cross } \\
\text { section }\end{array}$ & $\begin{array}{l}\text { Patents } \\
\text { counts }\end{array}$ & US industries & $\begin{array}{l}\text { In more than half of } \\
\text { these industries, patents } \\
\text { increase with industry } \\
\text { sales but at less than } \\
\text { proportionate rate }\end{array}$ \\
\hline $\begin{array}{l}\text { Pavitt et al } \\
\text { (1987) }\end{array}$ & $\begin{array}{l}4378 \\
\text { innovations } \\
1945-1983\end{array}$ & UK & $\begin{array}{l}\text { Cross } \\
\text { section }\end{array}$ & $\begin{array}{l}4378 \\
\text { significant } \\
\text { innovations }\end{array}$ & $\begin{array}{l}\text { UK } \\
\text { employment }\end{array}$ & $\begin{array}{l}\text { The relationship } \\
\text { between innovative } \\
\text { activity and firm size } \\
\text { may well be } \\
\text { increasingly U shaped. }\end{array}$ \\
\hline $\begin{array}{l}\text { Audretch } \\
\text { and } \\
\text { Acs(1991) }\end{array}$ & $\begin{array}{l}732 \text { large } \\
\text { firms }\end{array}$ & US & $\begin{array}{l}\text { Cross } \\
\text { section }\end{array}$ & $\begin{array}{l}\text { Number of } \\
\text { innovations }\end{array}$ & $\begin{array}{l}\text { Firms with } \\
\text { more than } \\
500 \\
\text { employees }\end{array}$ & $\begin{array}{l}\text { Innovations increased } \\
\text { less } \\
\text { proportionately } \\
\text { firm size }\end{array}$ \\
\hline $\begin{array}{l}\text { Cohen and } \\
\text { Klepper(1 } \\
\text { 994) }\end{array}$ & $\begin{array}{l}196 \\
\text { industrial }\end{array}$ & US & $\begin{array}{l}\text { Cross } \\
\text { section }\end{array}$ & $\begin{array}{l}\text { R\&D } \\
\text { expenditure }\end{array}$ & US industries & $\begin{array}{l}\text { A positive and } \\
\text { statistically significant } \\
\text { impact of business unit } \\
\text { size on R\&D } \\
\text { expenditure }\end{array}$ \\
\hline $\begin{array}{l}\text { Arvanitis } \\
\text { (1997) }\end{array}$ & $\begin{array}{l}\text { 2-digit } \\
\text { industries }\end{array}$ & Swiss & $\begin{array}{l}\text { Cross } \\
\text { section }\end{array}$ & $\begin{array}{l}\text { R\&D } \\
\text { expenditure }\end{array}$ & $\begin{array}{l}\text { Swiss } \\
\text { employment }\end{array}$ & $\begin{array}{lr}\text { Small firms } & \text { can } \\
\text { innovate } & \text { without } \\
\text { noticeable } & \\
\text { disadvantages } & \end{array}$ \\
\hline $\begin{array}{l}\text { Boasm } \\
\text { and De } \\
\text { Wit (2004) }\end{array}$ & $\begin{array}{l}66 \\
\text { industries }\end{array}$ & $\begin{array}{l}\text { Netherla } \\
\text { nd }\end{array}$ & $\begin{array}{l}\text { Cross } \\
\text { section }\end{array}$ & $\begin{array}{l}\text { Product } \\
\text { innovation }\end{array}$ & $\begin{array}{l}\text { Dutch } \\
\text { employment }\end{array}$ & $\begin{array}{l}\text { There is a positive } \\
\text { relationship between } \\
\text { product innovation and } \\
\text { firm size }\end{array}$ \\
\hline
\end{tabular}

It can be seen from Table 2 that some studies have indeed found a positive relationship between firm size and technological change (Scherer, 1965, 1984). On the other hand, there are some studies have identified no relationship or even a negative one (Cohen and Klepper, 1994). Aduretch and Acs(1991) argue that there are two mean reasons for these inconsistent findings. The first is that different measures have been used to quantify technical change (e.g. patents, $R \& D)$. The second reason is that most studies examining the relationship between firm size and technical change has had to use a truncated distribution of firm sizes where either no or few small firms were included. 


\section{Data}

The questionnaire was administered during August 2014. The data for this paper was collected using a standardized questionnaire. 100 questionnaires were distributed to small and medium sized firms in several cities in Egypt. The total response was 70 useable replies. The response rate of $70 \%$ was reasonable. The questionnaire contained 7 questions. The first three questions concerning financial data about the firms such as turnover, exports and capital. Question 4 asked about the number of employees .Firms are asked- in Question 5 to specify their market on a scale of 1-4 $(1=$ local,2= regional, $3=$ national, or $4=$ international.

Questions 6 and 7 focused on product and process innovation as question 6 asked if the firm has introduced a product which is new to the firm while question 7 asked if the firm has introduced a process which is new to the firm. According to question 6, a product innovation is the market introduction of a new or significantly improved good or service with respect to its capabilities, user friendliness, components or sub-systems.

- Product innovations (new or improved) must be new to your enterprise, but they do not need to be new to your market.

- Product innovations could have been originally developed by your enterprise or by other enterprises or institutions.

According to question7, a process innovation is the implementation of a new or significantly improved production process, distribution method, or supporting activity.

- Process innovations must be new to your enterprise, but they do not need to be new to your market.

- The innovation could have been originally developed by your enterprise or by other enterprises or institutions.

The answer of Questions 6 or 7 treated as a dummy variable takes 1 if the firm introduced new product or process and 0 if not. 


\section{Methodology}

In this section I present mymodelwhichbuilds on the model of Scherer (1965), Audretsch and Acs (1991) and Roges (2004). Scherer (1965) studied the relationship between the patenting and sales, using the following equation to identify the relationship between innovation and firm size:

$P_{i}=\alpha_{1}+\alpha_{2} S_{i}+\alpha_{3} S_{i}^{2}+\alpha_{4} S_{i}^{3}+u_{i}$

Where $P$ is patents and $S$ is sales.

Scherer (1965) found a positive relationship between the patents and sales.Audretsch and Acs (1991) used the same model but they used the number of innovations as a dependent variable instead of patents but they also found a positive relationship between the innovation numbers and sales.

Roges (2004), used a probit model to study the relationship between the innovation activity and the firm size. The author found a positive relationship between the innovation activity and size.

In this section the model of Scherer (1965), Audretsch and Acs (1991) and Roges (2004) are developed, using logit model to study the relationship between the innovation activity and sales.

The following equation will be estimated

$I A_{i}=\alpha_{1}+\alpha_{2} T U_{i}+\alpha_{3} T U_{i}^{2}+\alpha_{4} T U_{i}^{3}+u_{i}$

From equation (2) it can be seen that the innovation activity can be used as a dependent variable (this is a dummy variable which has value 1 if the firm has engaged in any innovation activity or 0 otherwise (King et al, 2005)). On the other hand the turnover $(T U)$ can be used as independent variable. Moreover, variables as control for unobserved heterogeneity such as regional dummies and market size dummies can also be used. the Scherer (1965) model which allows for non-linear impact of size on innovation is used here. 
When $I A$ is regressed non-linear on $T U$, the second derivative $\frac{d^{2} A I}{d T U^{2}}$ of the estimated function expected to be positive, $A I$ is increasing at an increasing rate with $T U$, and so innovation activity must generally be increasing more than proportionately with turnover. A negative second derivative implies the opposite relationship.

\section{Table 3 Innovation Activity}

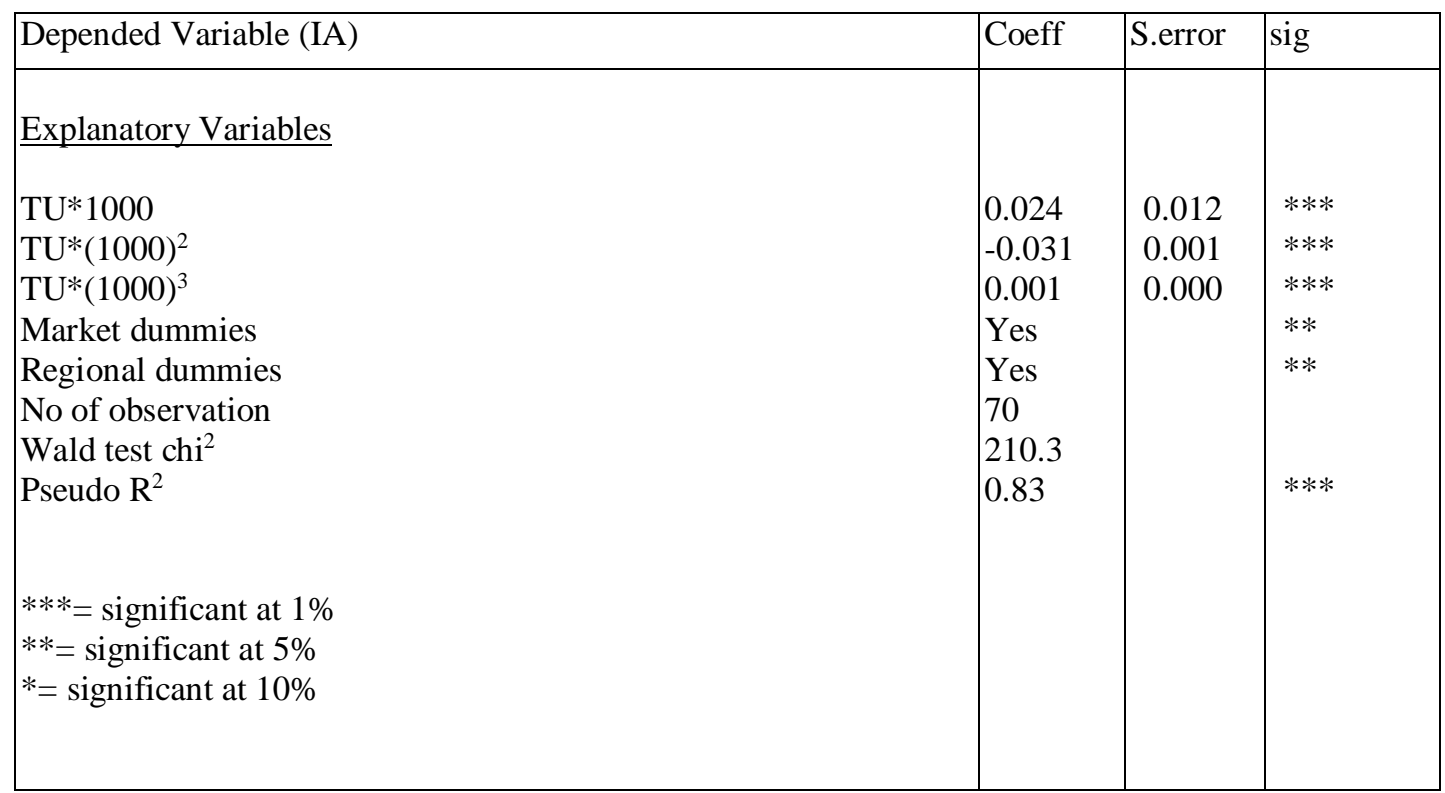

From Table 3 it can be seen that the relationship between the innovation activity and turnover is positive and significant at $1 \%$. (The innovation activity is a dummy variable indicating whether enterprise undertakes innovation activity.(Questions 6 and 7 in the questioner actually answer this question). This result supports the Schumpeterian hypothesis about the positive relationship between the innovation and firm size. It can be seen that the coefficient of the squared turnover (TU) is negative and this means that the innovation activity increases at a decreasing rate with TU. However the presence of a significant and positive term in the cube of the turnover means that the relationship may be more complex. Moreover, the market and regional dummies are positive and significant at $5 \%$. 


\section{Conclusions}

The paper examines the relationship between the innovation activity and the firm size.This research administers a questionnaire- based survey developed from the UK Innovation Survey (CIS). The survey covers quantitative and qualitative information addressing the innovation activities in the small and medium sized firms in Egypt during the period 20102012. The sample covers manufacturing firms in different regions in Egypt such as north, middle and Upper Egypt as well.

This paper has found that there is a positive relationship between the size firm and innovation. The chief conclusion concerns theresults provide solid evidence on of the innovation-firm size issue and the patterns emerging across firm size in Egyptian manufacturing small firms.

Moreover, our study has suggested improvements in the econometric techniques that are most appropriate to detect whether turnover has an effect on the innovation activity of both product and process innovations.

The main policy implications of these results are that innovation policies should explicitly identify their major objective and target group of firms. Efforts for stimulating new products should favour the strategies of market expansion by firms, through, for instance, an expansionary demand policy, organisation of new markets and targeted procurement. At the same time, when innovation in small and medium sized firms is targeted, the effectiveness shown by patenting in the introduction of new products suggests a strong policy potential of actions stimulating research and invention efforts by SMEs. 


\section{References}

Abousenna, N. M. and N. Becheikh (2012).“How Do Egyptian Service SMEs innovate”, 2012 AUC Research Conference, Cairo, Egypt

Arvanitis, S. (1997). "The Impact of Firm Size on Innovative Activity: An Analysis Based on Swiss Firm Data”, Small Business Economics, Vol.9, PP.473-490.

Audretsch, D.B. and Z.J.Acs (1991). "Innovation and Size Firm Level”, Southern Economic Journal, No.3 Vol. 57, PP739-744

Bosma, N. and G. De Wit (2004). "The influence of Firm Innovation on Firm Size.", Scientific Analysis of Entrepreneurship and SMEs (SCALES), Paper 200318

Breschi, S.F. Malerba and L. Orsemigo (2000).’Technological regimes and Schumpeterian Patterns of Innovation.", Vol. 110, PP.388-410.

Cohen, W. (1995).’Emprical Studies of Innovation Activity.” In (P.Stoneman(ed)). Hanbook of the Economics of Innovation and Technological Change., Oxford, Blackwell.

Cohen, W. and S. Klepper (1994).“A reprise of size and R\&D” Carnegie Mellon University, mimeo.

Deakins, D. and M. Freel (2003).Entrepreneurship and Small Firms. London, McGraw Hill.

Hippel, E. (1994). "Sticky Information and the Locus of Problem Solving: Implications for Innovation.” Management Sciences, Vol. 40, PP429-439

Hoffman, K., M.Parejo, J.Bessant and L.Perren (1998)."Small firms, R\&D, Technology and Innovation in the UK: A Literature Review.", Technovation, No.1, Vol. 18, PP 39-55.

Malerba, F. and L.Orsenigo (1995). "Schumpeterian Patterns of Innovation", Cambridge Journal of Economics, No. 1, Vol. 19, PP47-65

Mansfield, E. (1968). Industrial Research and Technological Innovation: An Econometric Analysis, London, Longmans, Green \&Co

Pavitt, R., M.Robson and J. Townsend (1987). "The Size Distribution of Innovating Firms in the UK 1945-83.” Journal of Industrial Economics, Vol. 35, PP 297-316

Rogers, M. (2004). "Network, Firm Size and Innovation: Evidence from Australian Firms." Small Business Economics, No. 2, Vol. 22, PP141-153

Schere, F.M.(1965). "Firm Size, Market Structure, Opportunity, and Output of Patented Inventions."American Economic Review, No. 5 vol.55, PP 1097-1125

Schere, F.M.(1984). Innovation and Growth: Schumpeterian Perspectives., Cambridge, Mass: MIT. 
Schumpeter, J. A. (1912). The Theory of Economic Development., Cambridge, Harvard Economic Studies.

Schumpeter, J. A. (1942). Capitalism, Socialism and Democracy., New York, Harper.

Simeonidis, G. (2001).'Innovation, Firm Size and market Structure: Schumpeterian Hypothesis and Some New Themes." OECD Economics Development Working Paper, No. 161

Storey, D.J. (1994) Understanding the Small Business Sector, London, Thomson Learning. 